\title{
Curriculum Development and Accreditation Standards in the Traditional Islamic Schools in Indonesia
}

* Institut Agama Islam Negeri Samarinda (State Islamic Institute of Samarinda), Samarinda, Indonesia.

E-mail:

muhammadnasir@iain-samarinda.ac.id

\section{Article Info}

Received: January 4, 2020

Revised: April 23, 2020

Accepted: June 21, 2020

\subsection{3/icsr.2020.3}

\section{How to cite}

Nasir, M. (2021). Curriculum Development and Accreditation Standards in the Traditional Islamic Schools in Indonesia. Journal of Curriculum Studies Research, 3(2), 3756.

https://doi.org/10.46303/icsr.2020.3

\section{Copyright license}

This is an Open Access article distributed under the terms of the Creative Commons Attribution 4.0 International license.

https://creativecommons.org/licenses/by/4.0/

\author{
Muhammad Nasir*
}

\section{ABSTRACT}

This research aims at describing qualitatively the reality of curriculum, instruction, and academic tradition development in madrasahs (traditional Islamic schools) based on the school/madrasah accreditation standards in Indonesia. The findings from this research show that madrasahs in Indonesia generally have met the standards of curriculum development and the model of Education Unit Level Curriculum in terms of mechanism, document completeness and involvement of external parties in its development. The aspects of planning, learning document availability, instructional book, learning load and study group generally have met the standards of national accreditation. The weaknesses lie in the aspects of development, contents, strategy, study resources, media, model, approach and learning method that support the strengthening of students' Higher Order Thinking Skills (HOTS). The creation of academic atmosphere is weak when it comes to 1) conditioning students to become true life-long learners, 2) enhancing students' skill to think creatively, productively, and critically, 3) applying scientific approaches such as study tours, practices in the laboratory, seminars, demonstrations, and exhibitions and 4) strengthening students' skill to act individually, collaboratively, and communicatively.

\section{KEYWORDS}

Curriculum development; madrasah; traditional Islamic schools; accreditation standards; Indonesia. 


\section{INTRODUCTION}

Educational system in Indonesia comprises two main subsystems - the general school education, which is under the administration of the Ministry of Education and Culture (MOEC); and the madrasah education under the Ministry of Religious Affairs (MORA) - which maintains an oversight over both public and private madrasahs across the country. The Law on National Education NO. 20 year 2003 formally integrates all madrasahs into the national education system, and they are required to follow the national curriculum and education standards set by the government. Approximately $18 \%$ of all Indonesian schools (primary and secondary) are madrasahs, with the majority (90\%) being private madrasahs and only $10 \%$ being run by the state. In $2013,87 \%$ of about 50 million students in the primary and junior secondary education system were enrolled in MOEC schools, while the remaining $13 \%$ were enrolled in madrasahs (Asian Development Bank, 2015).

In the face of the Industrial Revolution 4.0, madrasah as one of the Islamic educational institutions surely faces a serious challenge. Supriatna and Ratnaningsih states that the challenges of madrasah in the globalized era include the rapid development of technology, particularly the information and communication technology, the existence of dominant culture coming from advanced countries that challenge Muslim identities and Islamic values, the integration of the world's community, and the changing social expectation towards educational institutions (Supriatna and Ratnaningsih, 2017). In addition to the external demands, madrasah also faces internal challenges as a basic and secondary educational institution with Islamic spirit. In defending the characteristics of madrasah, madrasah graduates are not only demanded to compete in the millennial era and the industrial revolution 4.0 by mastering a number of competencies in the general sciences but the graduates of madrasah should also maintain their identity by strengthening their Islamic philosophical, theosophical, and theological subjects. This study covers the fields of mantiq, nahwu, sharaf, al-muhadharah, al-insya (public speaking), tarikh tasyri' usul fiqh, fiqh (principles of jurisprudence), hadits, tafsir, balaghah, ma'ani, badi', bayan (the knowledge of interpretation or instrumental knowledge) (Bustamam-Ahmad, 2015).

In the face of the two aforementioned challenges, madrasah has to present itself as an Islamic educational institution that is capable of competing globally and provides quality assurance for the process and results of the study for their graduates. Quality in education can be defined as a setting vision, mission, goal and target of the learning quality of madrasah that is beneficial and viable to achieve for students; b) developing the objectives of learning that are valuable and assertive; c) involving the process of meeting the academic standards to achieve the expectation of the society and the demands of government, business, and industry, students' aspirations and needs, and the requirements of professional institutions. In Japan, for example, to globally competitive students, the government uses Programme for International Student Assessment (PISA) that aims to assess main competencies. The Japanese government has also prioritized the development of human resources that are needed to compete in the 
international community and PISA has a huge impact on the direction of Japanese education (Nakayasu, 2016).

In order to assure the quality of process and graduates of all schools/madrasahs in Indonesia, the Indonesian government applied the National Standards of Education for schools/madrasahs through the Government Regulation No. 32 Year 2013 (Peraturan Pemerintah RI Nomor 32, 2013). This government regulation sets up eight national standards of education that serve as a guideline for all educational units in Indonesia in managing education. The standards here are for the competencies of school graduates, standards of contents, standards of process, standards of educators and academic staff, standards for equipments and infrastructures, standards of funding, and standards of assessment. In observing the reality of curriculum development, the process of learning, and reality of academic tradition in madrasahs, the standards of graduate competencies, standards of contents, and standards of process are considered to include three aspects meant.

\section{THEORETICAL FRAMEWORK}

According to the Regulation of the Minister of Education and Culture No. 02, 03, and 04 Year 2017 on the National Accreditation Boards for Schools/Madrasahs, accreditation is an activity to assess the fitness of basic and secondary educational institutions, pre-school educational institutions, and non-formal education based on the criteria set forth to provide quality assurance in education (Peraturan Menteri Pendidikan dan Kebudayaan Nomor 002, 2017; Peraturan Menteri Pendidikan dan Kebudayaan Nomor 003, 2017; Peraturan Menteri Pendidikan dan Kebudayan Nomor 004, 2017). Accreditation in education is the process of an association or institution in evaluating the quality of an educational institution formally to evaluate whether an institution meets or exceeds certain requirements and criteria that have been set from the criteria or quality standards of education. This institution sets the standards designed to reflect the quality of healthy educational programs. This institution develops the procedures to decide whether an educational institution and program meet the standard. In addition to setting the criteria, the association or accreditation institution holds the responsibility to visit and evaluate an institution, and provides accreditation to programs and institutions that meet their criteria (Budiharso \& Tarman, 2020; Ibrahim, 2014).

In evaluating the quality of an educational unit, accreditation is one of the external forms of evaluation conducted by the government through the National Accreditation Board for Schools/Madrasahs (BAN S/M). The internal evaluation can also be done with certain educational units through other modes of evaluation. One of the modes of evaluation that can be applied is the qualitative evaluation mode called the Context, Input Product and Process (CIPP) model. This model was developed by Stuffleben and friends in a book called Educational Evaluation and Decision Making. Context evaluation includes teacher, learners, management, work facilities, work environment, regulation, role of school committee, society, and factors that 
affect the curriculum. Input evaluation includes levels of advantage of various things present in the context of curriculum implementation. Process evaluation includes the applicability of curriculum implementation that will show the strengths and weaknesses, and product evaluation that includes results of learning by comparing with standards set with implementation reality (Hasan, 2008; Nasir. 2017).

The task of the National Accreditation Board (BAN S/M) in Indonesia includes setting the policies and developing the accreditation system in line with the principle of continuous quality improvement nationally, formulating the criteria and instruments of accreditation to be proposed to the Minister, setting policies for implementing the accreditation, introducing policies, criteria, and instruments of accreditation, planning the target of accreditation nationally based on the Ministry's priority, evaluating the process of accreditation and follow up of the accreditation, monitoring and evaluating the National Accreditation Board (BAN) at the province level, providing recommendation based on the results of the accreditation, issuing the certificates of the results of accreditation to educational units, reporting the results of the accreditation to the minister, building collaboration with relevant shareholders at the national or international level, and run the administration of the National Accreditation Board (BAN). All of these tasks are based on the Regulation of the Minister of Education and Culture No. 002/H/AK/2017 on the Criteria and Instruments of Accreditation for General and Islamic Elementary Schools, No. 003/H/AK/2017 on the Criteria and Instruments of Accreditation for General/Islamic Middle School, and No. 004/H/AK/2017 on the Criteria and Instruments of Accreditation for General and Islamic High Schools. The 2017 instruments of accreditation is a unit that consists of instruments, technical instructions, supporting data, and scoring system.

Accreditation is aimed to provide information on the fitness of the educational unit whether or not they have met the requirements set by the National Standards for Education (SNP) through the recognition of the accreditation rank in supporting the quality assurance for accredited educational units and general public. This is important for a number of reasons, namely, a) as a reference to improve the quality of schools and school development plan; b) as a motivator for the educational unit in order to e able to compete comprehensively in improving the quality of education at the regional, national, or even international levels, c) as beneficial feedbacks in improving school performance in implementing the vision and mission, quality target; d) as information for schools as a learning community to gain supports from the government, community and private sectors in terms of professionalism, morality, human resources, and finance. In short, the function of accreditation includes recognition of the worthiness and accountability for public as the end users of the service, whether their demands have been met, and the improvement and development as a basis for all parties to improve and develop the quality of their education (Haryati; 2014).

The ideal demand of curriculum development for madrasahs is reflected in the content standards of accreditation. Ideally, the curriculum of madrasahs has to be developed with the Curriculum of Educational Unit Level (KTSP) (Muhaimin et al., 2008; Nasir, 2015). The model 
criteria in general include: a) the formation of a madrasah curriculum developer team in charge of developing madrasah curriculum, involving various parties such as teachers of all subjects, counselors, madrasahs committee or educational administrators; b) the implementation of development procedures such as analysis of regulations, students' needs, educational unit, environment, availability of educational resources; c) the execution of curriculum development workshops that involve various related parties; d) the contents of curriculum document include context analysis, fundamentals for the development of curriculum, principles of development, vision, mission, and objectives of educational units, curricular contents or the structure of curriculum, students' study load, teachers' work load, academic calendar, local contents and assessment, syllabus with its various components, and the Lesson Plan (RPP) with the component standards inside (Peraturan Menteri Pendidikan dan Kebudayaan Nomor 002, 2017; Peraturan Menteri Pendidikan dan Kebudayaan Nomor 003, 2017; Peraturan Menteri Pendidikan dan Kebudayan Nomor 004, 2017).

The ideal demand of learning process in madrasahs is reflected in the standards of learning process and curriculum. Ideally, teachers have to: a) develop teaching media with their various components; b) apply the principles of proper learning; c) manage classes with a sense of humanity; d) choose a proper learning approach such as thematic approach and/or integrated thematic and/or scientific, student-centered approach and teacher-centered approach (Arends, 2007); c) use a learning model that is in line with the characteristics of subjects such as inquiry learning (Khalaf and Zin, 2018; Eggen et al., 1979), project-based learning, cooperative learning, problem-based learning, collaborative learning, contextual teaching and learning, and so on; f) use learning methods that are in line with the characteristics of the materials and condition of students such as lecture, demonstration, discussion, independent study, simulation, brainstorming, case study, seminar, tutorial, deductive, and inductive, and so on (Peraturan Menteri Pendidikan dan Kebudayaan Nomor 22, 2016).

The creation of academic tradition in madrasahs is reflected in the standard of graduates' competencies that demands madrasahs to provide students with facilities for various activities or programs so that students: a) have a sense of spirituality; b) have social attitude; c) have characters that reflect the attitude of a true life-long learner; d) have attitude that reflects mental and physical health; e) have factual, conceptual, procedural, and metacognitive knowledge in accordance with their levels with regards to sciences, technology, society, surrounding community and nature, nation, and Country; f) gain learning experience such as local arts and culture; and g) gain learning experience using information about the environment logically, critically, and creatively through the use of learning sources (Peraturan Menteri Pendidikan dan Kebudayaan Nomor 002, 2017; Peraturan Menteri Pendidikan dan Kebudayaan Nomor 003, 2017; Peraturan Menteri Pendidikan dan Kebudayan Nomor 004, 2017). The program of creating academic atmosphere that can be developed by teachers or madrasahs can be activities embedded into subjects or work programs that are separate from the subjects. 
Chart 1: Theoretical Framework

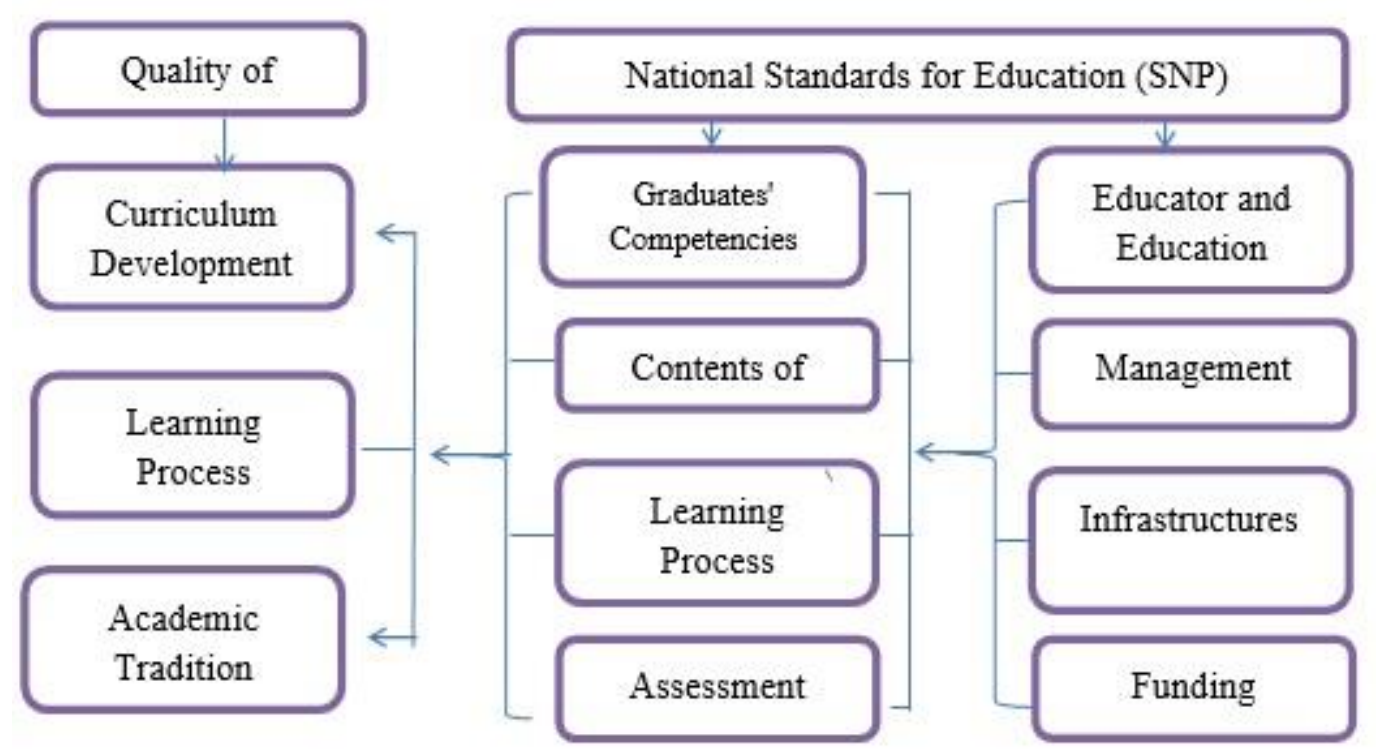

Based on the above chart, it can be explained that curriculum development, learning process, and the creation of academic tradition in madrasahs are the main foundations in shaping the quality of graduates without ignoring other factors. When related to the theories of curriculum, all three are included in the anatomy of curriculum or components of curriculum, namely, objective, contents, and learning materials, learning and assessment method or strategies. (Sukmadinata, 2008b; Miller and Seller, 1985; Undang-Undang RI Nomor 20, 2003; Print, 1993; Hamalik, 2008; Taba, 1971).

\section{METHODOLOGY}

This research uses a qualitative approach that aims to reveal comprehensively and in details the accreditation of madrasahs in East Kalimantan in 2017 involving thirty-three madrasahs, that include twelve Islamic Elementary School (Madrasah Ibtidaiyah/MI), fifteen Islamic Middle School (Madrasah Tsanawiyah/MTs), and six Islamic High Schools (Madrasah Aliah/MA).

The focus of this research is on curriculum development, learning process, and academic tradition in madrasahs in East Kalimantan based on the results of accreditation for madrasahs in 2017. The data obtained through documentation and interviews were analyzed qualitatively to find patterns, forms, ideas, and explanations and understanding of particular data elements. The resulting patterns and ideas were then interpreted to produce a conclusion.

The analysis on data from research results was conducted in three stages, namely: a) organizing data; b) summarizing data; and c) interpreting data (McMillan, 2012; Creswell, 2011; Sugiono, 2008; Sukmadinata, 2008a) and was concluded with drawing conclusion. In other words, the research process covers data collection, data categorization, data interpretation, and conclusion drawing (Moleong, 2011). 


\section{FINDINGS AND DISCUSSION}

The curriculum of an educational unit has conceptually been invented by a number of curriculum experts starting from the mechanism, document contents, and the involvement of related parties. Murry Print, for example, developed one model known as the eclectic model, which includes three stages of development, namely, curriculum organization, curriculum development, and curriculum implementation. (Print, 1993). Limbong mentions the stages of curriculum development for an educational unit as consisting of formulating thought model, formulation vision, mission, and objectives, formulating the structure of program contents, selecting and organizing materials, organizing learning activities, selecting resources and learning instruments, and selecting assessment model (Limbong et al., 2017) Ralph Tyler also proposes one model known as the rational model. Tyler explains four stages that a developer has to go through in developing curriculum, which departs from four questions, namely:

What educational purposes should the school seek to attain? What educational experiences can be provided that are likely to attain these purposes? How can these educational experiences be effectively organized? How can we determine whether the purposes are being attained? (Tyler, 1971)

Besides such model, there are still various curriculum development models that, when analyzed and compared with one another, are fundamentally more or less the same. In general, the core of all existing models is how a curriculum developer can develop the components of a curriculum, which include the objectives, contents, learning, and assessment.

\section{The Development Mechanism and Documents of Curriculum for Madrasahs}

Research results show that madrasahs in East Kalimantan have generally developed curriculum with the development model known as the Educational Unit Level Curriculum (KTSP) (Muhaimin et al., 2008; Mulyasa, 2009). Philosophically, this model means that the curriculum has to be developed and implemented by an educational unit by involving all components of the madrasah and various related parties by still referring to the national standards that have been set through the Government Regulation NO. 32 year 2013 and a number of Regulations from the Minister of Education and Culture as the derivatives.

Besides the development, contents or documents of curriculum for madrasahs in general meet the national standards for education in Indonesia. It is known that;

First, majority of the curriculum documents for madrasahs in East Kalimantan have been developed by both designing and developing the purposes that emphasize students' spiritual attitude (Core Competency 1), students' social attitude (Core Competency 2), students' knowledge (Core Competency 3) and students' skills (Core Competency 4). Under this condition, it can be ascertained that the curriculum documents for madrasahs in East Kalimantan in line with the national standards and concept of Islamic education that aims not only to develop intellectual intelligence and students' skills but also to develop social and spiritual intelligence as a whole and integrated. This integration of objectives is also reflected clearly in the Objectives 
of National Education as set forth in the Law on National Education System No. 20 Year 2003, which states "The potency development of learners into a believing and pious individual, with a noble character, healthy, knowledgeable, capable, creative, independent, and democratic as well as responsible as a citizen". This is in line with the domain of objectives as stated by Bloom, that is, the cognitive domain that is related with learners' capability and intellectual aptitude to think, a domain affectively related with attitude, capability, and mastery of emotional, feeling, attitude and values practiced by learners; and the psychomotoric domain related to the physical skills and movements of learners (Munir; 2008).

Second, the stages of developing curriculum and the contents of the curriculum documents for madrasahs in general have met the standards for curriculum contents for each educational unit levels (KTSP) because it has included context analysis, basis for the development of curriculum, principles of development, the tasks of elementary and secondary education, formulation of vision, mission, and the objectives of educational unit, structure and contents of curriculum, students' study load, teachers' work load, academic calendar, local contents, life skills, and class progression and assessment. This is seen from the documents of accreditation results that show that $85 \%$ of Islamic Elementary Schools (MI), $88.3 \%$ of Islamic Middle School (MTs), and $90.4 \%$ of Islamic High Schools (MA) have curriculum documents that are very complete or meet standards. This means that in general madrasahs in East Kalimantan have met the content standards for curriculum documents although it still cannot be ascertained whether those documents have been developed independently by educational units or whether they have been duplicated from the documents of other educational units of the same level.

Third, the curriculum documents for madrasahs with the development model of Curriculum of Educational Unit Level (KTSP) has been accompanied with curriculum structure that covers subjects, structured and independent assignment design, study load, selfdevelopment and arts, crafts, and entrepreneurship and local contents. If we map out the contents and documents of this madrasah curriculum, in general the curriculum documents for madrasahs have met the principles of curriculum development theoretically and the flow of education described by Diane Lapp in their book entitled Teaching and Learning: Philosophical, Psychological, Curricular Applications. In this book, we can find four schools of education, namely a) classical education. This school of education emphasizes on curriculum contents that support how students can master various disciplines through mastery of contents of various subjects both religious and non-religious subjects; b) personalized education. This school emphasizes the contents of curriculum that enable students to develop their potentials, talents, and interests through various self-development activities; c) interactional education. This school emphasizes the contents of curriculum that enable students to understand, review, and complete social problems through social interaction in the form of local contents with various forms; d) technological education. This school emphasizes the contents of curriculum that encourage students to have competency for real life needs (life skill). This last model can also 
mean that students have to be equipped with technological skills that are compatible with the technological advancement of the time (Lapp, 1975)

Table 1: The Completion of Development Mechanism and Documents Accreditation-based Curriculum for Madrasahs

\begin{tabular}{|c|c|c|c|c|}
\hline No & Statement of Accreditation Standards & $\begin{array}{l}\text { Islamic } \\
\text { Elementary } \\
\text { School } \\
\text { MI) /\% }\end{array}$ & $\begin{array}{l}\text { Islamic } \\
\text { Middle } \\
\text { School } \\
\text { (MTs)/\% }\end{array}$ & $\begin{array}{l}\text { Islamic } \\
\text { High } \\
\text { School } \\
\text { (MA)/\% }\end{array}$ \\
\hline 1 & $\begin{array}{l}\text { Curriculum documents that include the } \\
\text { competency of students' spiritual attitude } \\
\text { (KI1) }\end{array}$ & 81.8 & 91.7 & 87.5 \\
\hline 2 & $\begin{array}{l}\text { Curriculum documents that include the } \\
\text { competency of students' social attitude (KI2) }\end{array}$ & 84.1 & 90 & 95.8 \\
\hline 3 & $\begin{array}{l}\text { Curriculum documents that include the } \\
\text { competency of students' knowledge (KI1) }\end{array}$ & 88.6 & 83.3 & 91.6 \\
\hline 4 & $\begin{array}{l}\text { Curriculum documents that include the } \\
\text { competency of students' skill (KI1) }\end{array}$ & 79.5 & 83.3 & 91.7 \\
\hline 5 & $\begin{array}{l}\text { Instruments for the education of religion and } \\
\text { reason in line with the scope of the learning } \\
\text { materials }\end{array}$ & 90.9 & & \\
\hline 6 & $\begin{array}{l}\text { Integrated thematic learning media in line } \\
\text { with the competencies and scope of learning } \\
\text { materials on each class level. }\end{array}$ & 75 & & \\
\hline 7 & $\begin{array}{l}\text { Curriculum Documents are in line with the } \\
\text { level of competency and scope of learning } \\
\text { materials }\end{array}$ & & $88.3 \%$ & 79.17 \\
\hline 8 & $\begin{array}{l}\text { Curriculum development is in line with the } \\
\text { Education Unit Level Curriculum (KTSP) by } \\
\text { involving various related parties }\end{array}$ & 79.5 & 83.3 & 95.8 \\
\hline 9 & Curriculum documents completeness & 93.2 & 95 & 95.8 \\
\hline 10 & $\begin{array}{l}\text { Stages of curriculum development; analysis, } \\
\text { composition, decision, and legalization }\end{array}$ & 97.7 & 90 & 79 \\
\hline 11 & $\begin{array}{l}\text { Curriculum structure, structured and } \\
\text { independent tasks, learning load, self- } \\
\text { development and arts, craft, and } \\
\text { entrepreneurship. }\end{array}$ & 79.5 & 86.7 & 100 \\
\hline
\end{tabular}

Fourth, the weakness in the level of completion of the accreditation-based development mechanism and curriculum documents for madrasahs that are seen in table 1 below are; a) Islamic Elementary School (MI) is still weak in terms of curriculum development by involving related parties (79.5\%), completion of curriculum documents for Madrasahs that develop structured and independent tasks, self-development and arts, craft, and entrepreneurship comply with the standards (79.5\%), completion of integrated thematic learning instruments (75\%); b) Islamic Middle School (MTs) shows weakness in the curriculum development that 
include students' knowledge competency and skill competency (83.3\%) and the completion of curriculum development in line with the KTSP model that involve various related parties (83.3\%); c) Islamic High Schools (MA) show weaknesses in the stages of curriculum development in the form of analysis, composition, decision, and legalization (79\%) and the completion of curriculum documents in accordance with the level of competency and the scope of the learning materials (79.9).

With regards to the learning process in East Kalimantan madrasahs, there are 21 indicators of learning process quality for all education unit levels from Madrasah Ibtidaiyah (MI), Madrasah Tsanawiyah (MTs) to Madrasah Aliyah (MA). The twenty-one quality standard indicators can be divided into two big components if related to the tasks and responsibilities of learning process quality completion in the madrasah. First, the task and responsibility component of all madrasah teachers and, second, task and responsibility components of madrasah principles.

\section{Task and Responsibilities of Teachers in Learning Process Standard Completion}

One of the national standards in education in Indonesia is the educator and academic staff standard. Among the educator standards in Madrasahs is that educator has to have five basic competencies, namely, the pedagogical competence, personality competence, professional competence, and social competence (Kumalasari et al., 2017; Undang-Undang RI Nomor 14, 2005). Besides the above-mentioned four competencies, religion teachers Iso have to have one other competence, namely, the leadership competence. This last competence includes a) the ability of teachers to plan for setting the application of religious teachings and noble characters in the culture of school community as part of the process of learning religion; b) teacher's capability in organizing potentials of school elements systematically to support setting the application of religious teachings in the school community; c) teachers ability to become innovators, motivators, facilitators, guides, and counselors in the effort to set the application of religious teachings in the school community as part of the culture; and d) the ability of teachers to guard, control, and direct efforts to set the application of religious teachings in the culture of the school community and to maintain the harmony between believers of all religions in the fabric of the Republic of Indonesia (Peraturan Menteri Agama RI Nomor 16, 2010; Sanjaya, 2008).

The role of teachers today has changed and keeps changing from instructor to constructor, facilitator, coach, maintainer, and manager of students' learning environment. Teachers are demanded to become facilitators that help the learners make assessment on the quality and validity of sources and new knowledge, act openly and professionally, critically and independently, active cooperators, collaborator, and mediators between learners, differentiate between "learning about" and "learning to become," make structures and supporting system that support the development of students' skills such as interactive learning, collaborative and independent among students, developing a learning environment that support critical thinking, creativity, and scientific learning among students, turning students into learners and life-long 
innovators (Amin, 2016). Teachers have to be encouraged to work in an interdisciplinary manner (Alvunger, 2018) or not only understanding one discipline.

In general, the learning process quality in madrasahs is already very good based on Table 2 below, especially with regards to a) completeness of lecturers' syllabus that complies with the standards b) completeness of Lesson Plan; c) the availability of time allocation and learning load, d) the completion of learning group standards for each grade; e) the completeness of text books for each student; $f$ ) the ability of teachers to manage classes; g) the ability of teachers to open and conclude sessions. However, the aspects that constitute the weak points of the learning process of madrasah teachers are also found, especially related to the following matters:

First, the majority of madrasah teachers use the expository learning model. This can be seen among Islamic High School (MA) teachers (79.17\%) and Islamic Middle School (MTs) teachers (80\%) who use the learning model that emphasizes student's discovery and inquiry. This is contrary to the theory of child development. The age range of Islamic High School (MA) and Islamic Middle School (MTs) students, which is from 15 to 18, according to the theory of child development, allows children to think critically, solve problems, do independent research and develop knowledge through scientific research (Suryabrata, 2007; Slavin, 2018; Dahar, 1989). Therefore, at this level, teachers are no longer supposed to follow the curriculum that centers on transmitting knowledge to students, but they have to also be able to facilitate students to develop their knowledge independently through constructivistic learning model such as discovery learning, project based learning, problem-based learning, and inquity learnng At this point, students' competency is not only limited to the concepts of various subjects, but also various skills that are known as higher order thinking skill (HOTS). The effort to improve HOTS among students of higher levels is in line with the discourse of improving the quality of learning process to achieve maximum learning. One of the main characteristics of successful learning is reflected in knowledge, attitude, and skills shaped by habits and improvement of HOTS among students in a well-structured design (Ramdiah et al., 2019; Hanafi, 2016; McNeil, 2009).

Second, madrasah teachers still need to elaborate and combine various learning methods such as teaching methods that involve lectures, demonstration, seminar, tutorial, deduction, brainstorming, discussion, independent learning, simulation, case studies. This can be seen in Table 2 that Islamic Elementary Schools (MI) teachers (76.6\%), Islamic Middle Schools (MTs) teachers (75\%), and Islamic High School teachers (77.5\%) elaborate and combine well various learning methods. If we relate the objectives of learning in madrasahs with four categories, namely, spiritual, social attitude, knowledge and skill, then madrasah teachers have to understand well various learning methods. There are four families of teaching models offered by Joyce and Weil, namely, the humanistic model family, which aims to strengthen students' spiritual aspect; the information processing model family, which aims to strengthen students' cognitive aspect; the technological model family, which targets students' skills, and; the social 
model family, which aims to build students' social attitude (Joyce and Weil, 1996; Ramayulis, 2008; Daradjat, 2004).

Third, the use of teaching media by teachers needs to be increased by considering the technological and scientific advancement. The level of satisfaction in Islamic Elementary School (MI) is 79.5\%), Islamic Middle School (MTs) (85\%), and Islamic High School (MA) (79.2\%). In the era of information and technological advancement such as today, madrasah teachers are supposed to be innovative and creative in developing and utilizing various learning media that are in line with the characteristics of students and the basic competence targeted by each subject. The works of teachers or the available media are supposed to be maximized by teachers to improve the interest and learning achievements of learners. UNESCO revealed that various computer-based technology has been utilized, such as to distribute lesson plans through CDROM's, arrange exchange programs through computer-conferences among schools and teachers, encourage the utilization of web-based materials, and use computer conferences to encourage discussions among learners (Nasrullah, 2014; Bostock, 2017).

Fourth, the completeness of text books for students is still considerably low. Only $84.1 \%$ of Islamic Elementary Schools (MI), 85\% of Islamic Middle Schools (MTs) and $79.17 \%$ of Islamic High Schools (MA) have textbooks available for each subject for each student. Ideally, there should not only be one learning source, i.e. text books, for students, but also other learning sources to widen and deepen students' horizon about various topics of studies.

Fifth, the learning approach of madrasah teachers still need to be strengthened with student-centered approach in line with the view (Arends, 2014) and approach of scientific learning called for by the 2013 curriculum in Indonesia. Scientific in this manner is divided into three categories, namely: a) scientific activities towards affective competence through the affective process from the activities of accepting, practicing, appreciating, internalizing, and exercising; b) scientific activities towards knowledge through knowing, understanding, applying, analyzing, evaluating, and creating, and c) scientific activities for skill mastery through the activities of observing, questioning, trying, rationalizing, presenting, and creating (Peraturan Menteri Pendidikan dan Kebudayan Nomor 22, 2016). Table 2 below shows that $84.1 \%$ of Islamic Elementary School (MI) teachers, $81.7 \%$ of Islamic Middle School (MTs) teachers, and $8035 \%$ of Islamic High School (MA) teachers have applied combined learning methods that combine the teacher-centered approach and the student-centered approach. With this approach, it can be ascertained that students can develop knowledge to the best of their individual potentials.

Sixth, madrasah teachers have not maximized the use of authentic assessment in class, workshops, laboratories, or in their internship places through questionnaires, observation, anecdotes, and reflections. This can be seen in the fact that $78.3 \%$ of Islamic Middle Schools (MTs), 79.2\% of Islamic High Schools (MA), and $81.8 \%$ of Islamic Elementary Schools (MI) have maximized the use of authentic assessment. Characteristically, students of Islamic High School (MA) and Islamic Middle Schools (MTs) can well use the assessment desired by the government to improve their critical, creative, innovative, and collaborative thinking abilities continously. 
The weakness can be seen in the utilization of assessment results to conduct learning improvement through enrichment and remedial. Teachers have to see students individually to identify their uniqueness. Therefore, humanistic approach with various treatments have to be applied well by madrasah teachers in East Kalimantan. Remedial and enrichment activities are manifestations of humanistic approach in learning. This is in line with the view and agenda of education for United Nations council that education is a fundamental human right and the right that enables a person to achieve more, education is a public right and education is gender equality that is strongly related to education for all (Webb et al., 2017).

Table 2: The Completion of Teacher's Tasks in the Learning Process in Accreditation-based Madrasahs

\begin{tabular}{clccc}
\hline No & Statement of Accreditation Instruments & $\begin{array}{c}\text { Islamic } \\
\text { Elementary } \\
\text { School } \\
\text { (MI)/\% }\end{array}$ & $\begin{array}{c}\text { Islamic } \\
\text { Middle } \\
\text { School } \\
\text { (MTs)/\% }\end{array}$ & $\begin{array}{c}\text { Islamic } \\
\text { High } \\
\text { School } \\
\text { (MA)/\% }\end{array}$ \\
\hline 1 & Syllabus standards completion & 97.7 & 90 & 100 \\
2 & Lesson Plan & 88.6 & 78.3 & 87.5 \\
3 & Time Allocation and Learning load & 93.2 & 96.7 & 100 \\
4 & Study Batch & 88.6 & 93.3 & 91.67 \\
5 & Text book completeness & 84.1 & 85 & 79.17 \\
6 & Classroom management & 88.6 & 88.3 & 87.5 \\
7 & Opening Class & 88.6 & 86.7 & 91.6 \\
8 & Selection of learning model & 86.4 & 80 & 79.17 \\
9 & Implementation of learning model & 76.6 & 75 & 77.5 \\
10 & Utilization of Learning Media & 79.5 & 85 & 79.2 \\
11 & Selection of learning source to use & 81.8 & 90 & 87.5 \\
12 & Learning approach selected & 84.1 & 81.7 & 80.3 \\
13 & Closing Lesson & $81.8 \%$ & 86.7 & 87.5 \\
14 & Utilization of Authentic Assessment & 81.8 & 78.3 & 79.2 \\
15 & Utilization of Assessment Results & 81.8 & 75 & 87.5 \\
\hline
\end{tabular}

Therefore, teachers have to have skills related to the three domains in achieving the maximum quality of process and learning results in line with the objective, namely, the skills in designing curriculum, mastering pedagogical contents, and the skill in curricular consistency. This shows that teachers are curriculum designers (Huizinga et al., 2014). With regards to madrasahs, teachers have to master the materials of Islamic Studies, master pedagogy, and understands research methodology.

\section{Task and Responsibilities of Madrasah Principals in the Learning Process}

Madrasah principals do not only serve as the leader and manager but also serve as the superintendent. The superintendent role of madrasah principals has a significant relation with teachers' competence. This means that: a) teachers will have competence if the madrasah principals as school superintendents are involved actively in overseeing teacher's curriculum 
design; b) teachers can understand problems and can make wise decisions that influence students' education; c) teachers can do their tasks and perform their main functions and improve students' learning achievements. Therefore, principals serve as the observers, superintendents, evaluators, and successors (Purwanto, 2017). Effective leadership of a madrasah principal can be seen from the aspect of effective implementation of leadership, instructional leadership, maintaining the atmosphere that centers on students, professional development and human resources management, involving parents and partnership with public, managing madrasahs effectively and implementing daily programs, applying effective interpersonal relations (Wahyuddin, 2017). Madrasah principals have to create the right condition to expand the field of studies, such as equality, environment, sex education, and drugs abuse in their teachings (Alvunger, 2018).

Table 3: The Satisfaction of Madrasah Principals' Tasks in the Standards of Accreditation-Based Learning Process

\begin{tabular}{|c|c|c|c|c|}
\hline No & Statement of Accreditation Instruments & $\begin{array}{c}\text { Islamic } \\
\text { Elementary } \\
\text { School } \\
\text { (MI)\% } \\
\end{array}$ & $\begin{array}{c}\text { Islamic } \\
\text { Middle } \\
\text { School } \\
\text { (MTs) } \\
\end{array}$ & $\begin{array}{l}\text { Islamic High } \\
\text { School (MA) }\end{array}$ \\
\hline 1 & $\begin{array}{l}\text { Transparent and objective overseeing of } \\
\text { learning process }\end{array}$ & 88.6 & 86.6 & 87.5 \\
\hline 2 & $\begin{array}{l}\text { Conducting supervision of madrasah } \\
\text { teachers' learning }\end{array}$ & 88.6 & 90 & 79.1 \\
\hline 3 & $\begin{array}{l}\text { Monitoring the learning process by } \\
\text { madrasah teachers }\end{array}$ & 84.1 & 85 & 79.1 \\
\hline 4 & $\begin{array}{l}\text { Follow up on the results of supervision } \\
\text { on the learning process by madrasah } \\
\text { teachers }\end{array}$ & 88.6 & 76.7 & 91.6 \\
\hline 5 & $\begin{array}{l}\text { Principals compose a report on learning } \\
\text { monitoring }\end{array}$ & 77.3 & 78 & 83.3 \\
\hline 6 & $\begin{array}{l}\text { Realization of the follow up on the } \\
\text { supervision results of learning process }\end{array}$ & 79.5 & 80 & 79.1 \\
\hline
\end{tabular}

The reality of level of task completion of madrasah principals on the standards of learning process for madrasahs in East Kalimantan, seen in Table 3 above. In general, the main tasks and functions of madrasah principals as superintendents and to monitor that the learning process by teachers is running well. In particular, the weakness is seen in the performance of supervision on the learning process by Islamic High School (MA) teachers (79.1\%) and the follow up on the supervision results on the learning process by madrasah principals in Islamic Middle Schools (MTs) (76.7\%). The weakness is on all levels in the performance of the monitoring of learning process by teachers, the composition of monitoring reports on the learning process and the realization of the monitoring results on the learning process by madrasah principals. 
The implementation of supervision on the learning teaching and teaching by madrasah teachers to make sure that teachers are more effective in teaching in the classroom and to assure that the quality can be improved from time to time. The instruments for supervising teachers' performance developed by Puteri Darishah et al. in Kubang Pasu Middle School. Kedah Malaysia consisting of three aspects, namely: a) teaching and learning supervision instrument in the forms of knowledge, interpersonal skills and technical skills; b) attitude of teachers instrument and c) competency of teaching instrument that includes teaching strategies techniques, and method, communication with students.and the participation of student (Darishah et al., 2017). School principal serves as an effective manipulator of teacher activity, he/she has to be smart, high initiative, and with the ability to supervise effectively. Experts like Ukeje, Ogunsanju and Nwaogu has identified four techniques of supervision by principals, namely: a) classroom visitation, which is the visit by principals to classrooms to see in person how teachers and students interact; b) workshop techniques, i.e. offering a group of people working together to identify problems and provide solutions to them during discussion and conferences under the supervision of sources and professionals; c) micro-teaching technique that gives the opportunity to superintendents and teachers to identify, define, try, explain, analyze, and retry certain teaching skills; d) research technique, i.e. investigating, which leads to new facts that need the use of research because it is related to factual observation in teaching-learning situation. Through research, super intendents can solve problems of education that can ad to professional knowledge and growth as well as those of the teachers bellow them (Hamalik, 2008).

\section{Competence of Madrasah Graduates in Indonesia}

To achieve graduates that meet the standards set by the National Education Standards, madrasahs have to have a good program of academic creation in every subject or program or activity independent from subjects. The description of the academic creation for madrasahs in East Kalimantan is as described in Table 4.

Table 4 provides the information that Islamic High Schools (MA) have several weaknesses in the creation of academic atmosphere to achieve the objectives or graduates' competence. Efforts to condition learners to become true lifelong learners is very low and far from the national standards for education, which are 63.3\% for Islamic Elementary Schools (MI), 76.7\% for Islamic Middle School (MTs), and 62.5\% for Islamic High Schools (MA). Other weaknesses can also be seen in Islamic Middle Schools (MTs) and Islamic High School (MA) in terms of the strengthening of students' creative, productive, and critical thinking through scientific approaches, such as study tours, laboratory practices, seminar and demonstration, and exhibition and strengthening of students' skill in acting independently, collaboratively, and communicatively through individual and group assignment, task reporting, presenting assignment results, involvement in committees, and involvement in various academic writing contests are done seriously by $16.66 \%$ of all madrasahs. 
Table 4: The Satisfaction of Academic Atmosphere Creation for Madrasahs Based on Accreditation.

\begin{tabular}{|c|c|c|c|c|}
\hline No & Statement of Accreditation Instruments & $\begin{array}{l}\text { Islamic } \\
\text { Elementary } \\
\text { School } \\
\text { (MI)\% }\end{array}$ & $\begin{array}{l}\text { Islamic } \\
\text { Middle } \\
\text { School } \\
\text { (MTs)\% }\end{array}$ & $\begin{array}{l}\text { Islamic High } \\
\text { School } \\
\text { (MA)\% }\end{array}$ \\
\hline \multirow[t]{2}{*}{1} & Strengthening sense of belief and piety to God & & & \\
\hline & Almighty among students & 93.2 & 98.3 & 91.7 \\
\hline 2 & Strengthening students' social attitude & 86.4 & 98.3 & 95.8 \\
\hline 3 & Conditioning students to be true learners & 63.6 & 76.7 & 62.5 \\
\hline 4 & Activities of students' physical fitness & 86.4 & 95 & 87.5 \\
\hline 5 & $\begin{array}{l}\text { Strengthening students' factual, conceptual, } \\
\text { procedural and metacognitive knowledge }\end{array}$ & 79.5 & 86.7 & 83.3 \\
\hline 6 & $\begin{array}{l}\text { Strengthening of talents in local arts and } \\
\text { culture among students } \\
\text { Creation of learning experiences in the forms }\end{array}$ & 77.3 & - & - \\
\hline 7 & $\begin{array}{l}\text { of information on surrounding environment } \\
\text { logically, critically, and creatively }\end{array}$ & 84.1 & - & - \\
\hline 8 & $\begin{array}{l}\text { Strengthening the ability to think creatively, } \\
\text { productively and critically among students } \\
\text { Strengthening students' skills to act }\end{array}$ & - & 71.7 & 75 \\
\hline 9 & $\begin{array}{l}\text { independently, collaboratively, and } \\
\text { communicatively }\end{array}$ & - & 81.7 & 75 \\
\hline
\end{tabular}

Several factors that might affect the weakness above in the creation of academic atmosphere in Madrasah in East Kalimantan, especially in Islamic Middle School (MTs) and Islamic High School (MA) to achieve the objectives or graduates competence, such as, the geographic condition of madrasah that is far from the city, the limited funding, motivation and discipline among teachers and students, the management of madrasah principal and the minimum infrastructures. Aside from various factors, the strengthening of teachers' competence and creativity of madrasah principals in managing the ducation unit based on quality (Arcaro, 2006) can be one of the ways to reduce such weakness. The success of a madrasah relies heavily on teachers and its leader. Madrasah leader is a person granted the authority to bring a madrasah to achieve its desired goal. The acquired trust is surely based on several factors. The behavior of madrasah leaders is one of the main factors that decides the capability of a madrasah to achieve its vision, mission, goals and targets. This describes that the attitude of every madrasah principal as a leader of an educational institution is directed towards helping achieve the objectives of curriculum and education, so the school principal is required to guide, direct, assign, oversee, assess the performance of teachers in schools/madrasahs that 
he/she leads (Purwanto, 2017; Mujtahid, 2011; Suparlan, 2013). Aside from madrasah principals, teachers also have to understand three areas that strongly support the strengthening of academic atmosphere in madrasahs, namely, through

a) konwledge of leaner and how they learn and develop within social contexts; b) conception of curriculum content and goal; an understanding of the subject matter and skill to be taught in light of the social purposes of education; c) an understanding on teaching in light of the content and learner to be taught, as informed by assessment and supported by classroom enviroments (Darling-Hommand, 2012).

The ways developed by madrasahs to create an academic atmosphere include, among others, first, developing the model for collaboration among madrasahs, families, and communities. Joyce Epstein, for example, developed one model of collaboration between families, madrasahs, and communities to strengthen the professionalism of teachers in a socalled Initial Teacher Education (ITE) Programmes. One of the emphases of this model is on the fact that teachers have to communicate routinely with parents, leaderships and communities or madrasah committee to achieve the goal of madrasahs that have been set (Willemse et al., 2018). Other factors include teachers' task to develop a learningt hat can develop students' critical thinking ability such as through simple debate in class. This debate can develop the critical, transformative, and philosophical thinking tradition among students (Moh Yamin, 2010). Educators have to be able to create a social atmosphere in the classroom that encourages curiosity among students and can develop students' knowledge independently through the process of assimilation, accommodation, disequilibration, and equilibration. Then, teachers have to develop Research Based Learning (RBL) that can change students' mindset, express things that are not known to students, train students to conduct simple research, improve academic achievements, promote learning process, and encourage students to develop knowledge (Suntusia et al, 2019). Dwi Nugroho offers the learning of surrounding environment, school at work, meaningful project, programmed project and center of attention (Hadiyanto, 2009).

\section{CONCLUSION}

Curriculum development for madrasahs, learning process, and creation of academic atmosphere are main factors in deciding the level of satisfaction of education goals with various categories. The main actor of this process are teachers and madrasah principals. Teachers have to understand various theories, policies, and implementation of curriculum and learning to face the advancement of science and technology, the demand and interest of the society and the characteristics of students in the millennial era.

A madrasah principal as the authority of an education unit has to understand the concept, main task, and functions particularly those related directly to the quality of graduates such as 
curriculum document development, learning and academic tradition of the madrasah through periodical and quality supervision and monitoring of learning process by teachers.

\section{REFERENCES}

Alvunger, Daniel. (2018). Teachers' Curriculum Agency in Teaching a Standards-Based Curriculum, The Curriculum Journal, 29(4), 1-20.

Amin, Jayendrakumar N. (2016). Redifining the Role of Teacher in the Digital Era, International Journal of Indian Psychology, 3(3), 40-45.

Arcaro, Jerome S. (2006). Quality in Education: An Implementation Handbook. New Delhi: Pentagon Press.

Arends, Richard I. (2014). Learning to Teach. New York: McGraw-Hill Higher Education.

Asian Development Bank. (2015). Education in Indonesia: Rising to the Challenges. Paris: OECD Publishing.

Bostock, William W. (2017). The Educational Use of Film and Television Documentary: Sugihara, Conspiracy of Kindness, Journal of Curriculum and Teaching, 6(2), 13-17.

Budiharso, T. \& Tarman, B. (2020). Improving Quality Education through Better Working Conditions of Academic Institutes, Journal of Ethnic and Cultural Studies, 7(1), 99-115. http://dx.doi.org/10.29333/ejecs/306

Bustamam-Ahmad, Kamaruzzaman. (2015). Educational Practice: Lessons to be Learned from Madrasah and Religious Schools in Contemporary Southeast Asia. Indonesian Journal of Islam and Muslim Societies, 5(1), 29-48.

Cresswel, John W. (2011). Educational Research: Planning, Conducting, and Evaluating, Quantitative and Qualitative Research. London: Allyn \& Bacon.

Dahar, Ratna Willis. (1989). Teori-Teori Belajar. Jakarta: Erlangga.

Daradjat, Zakiah. (2004). Metode Khusus Pengajaran Agama Islam. Jakarta: Bumi Aksara.

Darishah, P., Daud, Y., \& Fauzee, Mohd Sofian Omar. (2017). Teaching and Learning Supervision by School Management, Attitude of Teachers and Competency of Teaching, International Journal of Development and Sustainability, 6(10), 1367-1381.

Darling-Hommand, Linda, \& Bransford, John. (2012). Prepare Teacher for a Changing Word: What Teacher Should Learn and Be Able to Do. New York: Wiley.

Eggen, Paul D., Kauchak, Donald P., \& Harder, Robert J. (1979). Strategies for Teacher: Information Processing Models in Classroom. London: Prentice-Hall.

Hadiyanto, Dwi Nugroho. (2009). Pemikiran Kependidikan: Dari Filsafat ke Ruang Kelas. Jakarta: Artha Karya Indonesia.

Hamalik, Oemar. (2008). Dasar-Dasar Pengembangan Kurikulum. Bandung: Remaja Rosdakarya. Hanafi. (2016). The Effect of Discovery Learning Method Application on Increasing Students' Listening Outcome and Social Attitude, Dinamika IImu, 16(2), 291-306.

Haryati, Sri. (2014). An Evaluative Review of School Accreditation Implementation Program in Indonesian Contexts, International Education Studies, 7(5), 138-146.

Hasan, S. Hamid. (2008). Evaluasi Kurikulum. Bandung: Remaja Rosdakarya.

Huizinga, T., Handelzalts A., Nieveen, N., \& Voogt, Joke M. (2014). Teacher Involvement in Curriculum Design: Need for Support to Enhance Teachers' Design Expertise, Journal of Curriculum Studies, 46(1), 33-57.

Ibrahim, Hassan Al-Haj. (2014). Quality Assurance and Accreditation in Education, Open Journal of Education, 2(2), 106-110.

Joyce, Bruce, \& Weil, Marsha. (1996). Models of Teaching, Boston: Allyn \& Bacon. 
Khalaf, Bilal Khalid, \& Zin, Zuhana Bt Mohammed. (2018). Traditional and Inquiry-Based Learning Pedagogy: A Systematic Critical Review, International Journal of Instruction, 11(4), 545-564.

Kumalasari, Selvia P., Setiawan, Budhi, \& Sumarlam. (2017). Pedagogical Competence of Indonesia Teacher Viewed from the Anecdote Writing Lesson Planning, Lingua Didaktika, 11(2), 146156.

Lapp, Diane. (1975). Teaching and Learning: Philosophical, Psychological, Curricular Applications. New York: Macmillan.

Limbong, M., Syafaruddin, \& Fachruddin. (2017). The Implementation of Curriculum Development at Public Madrasah Aliyah in Aceh Tamiang Regency, International Journal of Humanities and Social Science Invention, 6(4), 17-25.

McMillan, James H. (2012). Educational Research: Fundamentals for the Consumer. Boston: Pearson.

McNeil, John D. (2009). Contemporary Curriculum: In Thought and Action. Chicester: John Wiley \& Sons.

Miller, John P., \& Seller, Wayne. (1985). Curriculum: Perspective and Practice. New York: Longman. Moleong, Lexy J. (2011). Metode Penelitian Kualitatif. Bandung: Remaja Rosdakarya.

Muhaimin, Sutiah, \& Prabowo, Sugeng Listyo. (2008). Pengembangan model kurikulum tingkat satuan pendidikan (KTSP) pada sekolah \& madrasah. Jakarta: Raja Grafindo Persada.

Mujtahid. (2011). Pengembangan Profesi Guru. Malang: UIN-Maliki Press.

Mulyasa, E. (2009). Kurikulum Tingkat Satuan Pendidikan, Kemandirian Guru dan Kepala Sekolah. Jakarta: Bumi Aksara.

Munir. (2008). Kurikulum Berbasis Teknologi Informasi dan Komunikasi. Bandung: Alfabeta.

Nasir, Muhammad. (2015). Kurikulum Madrasah: Studi Perbandingan Madrasah di Asia, Nadwa: Jurnal Pendidikan Islam, 9(2), 145-166.

Nasir, Muhammad. (2017). Pengembangan Kurikulum Pendidikan Islam, Syamil: Jurnal Pendidikan Agama Islam, 5(2), 147-167.

Nakayasu, Chie. (2016). School Curriculum in Japan, The Curriculum Journal, 27(1), 134-150.

Nasrullah. (2014). Role of Multimedia Tutorials in Distance Education, International Journal for Infonomics, 7(3/4), 933-941.

Peraturan Menteri Agama Republik Indonesia Nomor 16 Tahun 2010 Pengelolaan Pendidikan Agama pada Sekolah. 6 Desember 2010. Jakarta.

Peraturan Menteri Pendidikan dan Kebudayaan Nomor 002/H/AK/2017 Kriteria dan Perangkat Akreditasi SD/MI. 10 Maret 2017. Jakarta.

Peraturan Menteri Pendidikan dan Kebudayaan Nomor 003/H/AK/2017 Kriteria dan Perangkat Akreditasi SMP/MTs. 10 Maret 2017. Jakarta.

Peraturan Menteri Pendidikan dan Kebudayaan Nomor 004/H/AK/2017 Kriteria dan Perangkat Akreditasi SMA/MA. 10 Maret 2017. Jakarta.

Peraturan Menteri Pendidikan dan Kebudayan Nomor 22 Tahun 2016 Standar Proses Pendidikan Dasar dan Menengah, 6 Juni 2016, Jakarta.

Peraturan Pemerintah Republik Indonesia Nomor 32 Tahun 2013 Perubahan atas Peraturan Pemerintah Nomor 19 tentang Standar Nasional Pendidikan. 7 Mei 2013. Lembaran Negara Republik Indonesia Tahun 2013 Nomor 71. Jakarta.

Print, Murray. (1993). Curriculum Development and Design. Australia: Allen \& Unwim, 1993.

Purwanto, Djandji. (2017). The Role of School Principal and School Supervisors in Improving Teacher Competency in The Application of Leading Saintific Approach in Vocational High School, Jurnal Aplikasi Manajemen, 15(3), 389-398.

Ramayulis. (2008). Metodologi Pendidikan Agama Islam. Jakarta: Kalam Mulia. 
Ramdiah, S., Abidinsyah, Royani, M., \& Husamah. (2019). Understanding, Planning, and Implementation of HOTS by Senior High School Biology Teachers in Banjarmasin-Indonesia, International Journal of Instruction, 12(1), 425-440.

Sanjaya, Wina. (2008a). Kurikulum dan Pembelajaran: Teori dan Praktik Pengembangan Kurikukum Tingkat Satuan Pendidikan (KTSP). Jakarta: Kencana.

Sanjaya, Wina. (2008b). Strategi Pembelajaran: Berorientasi Standar Proses Pendidikan. Jakarta: Kencana.

Slavin, Robert E. (2018). Educational Psychology: Theory and Practice. New York: Pearson.

Sugiono. (2008). Metode Penelitian Pendidikan: Pendekatan Kuaalitatif, Kuantitatif dan Research and Development, Bandung: Alfabeta.

Sukmadinata, Nana Syaodih. (2008a). Metode Penelitian Pendidikan. Bandung: Remaja Rosdakarya.

Sukmadinata, Nana Syaodih. (2008b). Pengembangan Kurikulum: Teori dan Praktik. Bandung: Remaja Rosdakarya.

Suntusia, Dafik, \& Hobri. (2019). The Effectiveness of Research Based Learning in Improving Students' Achievement in Solving Two-Dimensional Arithmetic Sequence Problems, International Journal of Instruction, 12(1), 17-32.

Suparlan. (2013). Manajemen Berbasis Sekolah: Dari Teori sampai dengan Praktik. Jakarta: Bumi Aksara.

Supriatna, R. Dedi, \& Ratnaningsih, Sita. (2017). Indonesian Madrasah in the Era of Globalization. TARBIYA: Journal of Education in Muslim Society, 4(1), 89-103.

Suryabrata, Sumadi. (2007). Psikologi Pendidikan. Jakarta: Grafindo Persada.

Taba, Hilda. (1971). Curriculum Development: Theory and Practice. London: Harcourt Brace.

Tyler, Ralph W. (1971). Basic Principles of Curriculum and Instruction. Chicago; London: The University of Chicago Press.

Undang-Undang Republik Indonesia Nomor 14 Tahun 2005 Guru dan Dosen. 30 Desember 2005. Lembar Negara Republik Indonesia Tahun 2005 Nomor 157. Jakarta.

Undang-Undang Republik Indonesia Nomor 20 Tahun 2003 Sistem Pendidikan Nasional. 8 Juli 2003. Lembaran Negara Republik Indonesia Tahun 2003 Nomor 4301. Jakarta.

Wahyuddin, Wawan. (2017). Headmaster Leadership and Teacher Competence in Increasing Student Achievement in School, International Education Studies, 10(3), 215-226.

Webb, S., Holford, J., Hodge, S., Milana, M., \& Waller, Richard. (2017). Lifelong Learning for Quality Education: Exploring the Neglected Aspect of Sustainable Development Goal 4, International Journal of Lifelong Education, 36(5), 509-511.

Willemse, T. M., Thompson, I., Vanderlinde, R., \& Mutton, Trevor. (2018). Family-School Partnerships: A Challenge for Teacher Education, Journal of Education for Teaching, 44(3), 252-257.

Yamin, Moh. (2010). Manajemen Mutu Kurikulum Pendidikan: Panduan Menciptakan Manajemen Mutu berbasis Kurikulum yang Progresif dan Inspiratif. Yogyakarta: Diva Press. 